\title{
ANALYSIS OF THE INFLUENCE OF PESTICIDES ON THE SOIL IN AN AGRICULTURAL AREA
}

\author{
Beatrice Daniela TUDOR, Bianca Teodora BUCEVSCHI \\ "Dunarea de Jos" University of Galati, Romania \\ e-mail: beatrice.tudor@ugal.ro
}

\begin{abstract}
The paper presents an analysis of the soil in an agricultural area, to determine the influence of pesticides on the soil where agricultural production is carried out. For the research of the soil quality, were analysed areas, for harvesting soil samples. On the samples collected were determined, the amount of nitrates and nitrites from the soil, were determination of heavy elements from soil composition, soil pH and it was observed of the impact of pollutants on the soil.
\end{abstract}

KEYWORDS: pollutants, pesticides, nitrates, nitrites

\section{Introduction}

The soil represents the easy layer of the bark, having a thickness of a few $\mathrm{cm}$, up to 2-3 $\mathrm{m}$. It was formed as a result of simultaneous actions, such the atmosphere, hydrosphere and biosphere, on rocks and parenteral matter.

The chemical composition of the soil includes almost all known chemical, mineral and organic elements.

The mineral part of the soil is determined by its origin. The organic part of the soil is made up of animal and vegetable waste.

The amount of humus in the soil represents the natural fertility of the soil, which can be raised by applying organic fertilizers.

The soil has specific physical, chemical and morphological properties.

The physical properties of the soil include colour, texture, structure, porosity, density, consistency, temperature and air [1, 3].

The chemical properties are soil acidity, humification.

Soil pollution is defined by the presence of toxic substances (pollutants or contaminants) in the soil, in sufficient concentrations, to represent a risk, a health risk. Soil pollution, it is produced if the levels of soil contaminants, exceed the levels that should be present in a natural way.

The soil can be polluted by direct methods, i.e., by landfills, and by indirect methods, fertilizers and pesticides discarded on agricultural land; by the deposition of pollutants evacuated into the atmosphere; rainwater contaminated with pollutants; the transport of pollutants from the wind, from one place to another; infiltration through the soil of contaminated water.

The use of pesticides and chemical fertilizers has increased, for the cultivation of more crops, and these pollutants have made the soil poisonous and, in many places, the soil has become infertile $[2,5]$.

Pesticides, once in the soil, in addition to their action on diseases, pests, weeds, extend their action on microorganisms, so that there are quantitative changes and qualitative both in the structure of the edaphic population and in the physiological activities. The importance of knowing these changes is supported both by the requirements of a scientific agriculture and by the protection of soil ecosystems.

The chemicalization of agriculture through fertilizers, herbicides, pesticides, phytohormones is closely linked to both the increase in agricultural production and environmental problems $[6,8]$.

\section{Experimental research}

For the research of the soil quality, the following objectives were analysed:

- Establishment of affected areas, for harvesting soil samples;

- Determination of nitrates and nitrites from the soil;

- Determination of heavy elements from soil composition;

- Determination of soil $\mathrm{pH}$;

- Observation of the impact of pollutants on the environment. 
Soil sampling is one of the most important steps in a fertilization program. As soil sampling for laboratory analysis is done only from a not very large area of land, it is necessary to collect a representative soil sample for accurate results.

Soil samples were taken from the Bădălan agricultural production area, near the municipality of Galaţi. The sampling was done from two different areas and from each area it was selected as many samples from the different depths.

Most of the plant's roots have the highest biological activity and the highest nutrient, content on the surface, so, the first $30 \mathrm{~cm}$ of soil is tested and analysed. The soil samples were taken according to the depth as follows:

$-10 \mathrm{~cm}$ depth for sample 1 ;

- $20 \mathrm{~cm}$ depth for sample 2;

- $30 \mathrm{~cm}$ depth for sample 3 .

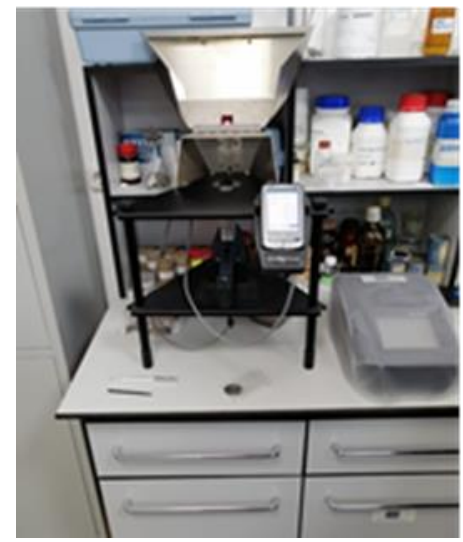

\subsection{Analysis of the concentration of heavy soil metals in soil samples}

The soil behaves as a depository of heavy metals emitted into the environment; behavior favoured by their ability to accumulate over time. Different factors can act on these deposits, being taken up in the form of particles in the air and water or being absorbed by plants.

Heavy metals have a potentially toxic effect on all living organisms, if they exceed a certain limit. The plants can accumulate heavy metals directly from the soil [4].

In order to be analysed, the soil samples were first dried in a thermoregulatory oven for 24 hours at $105{ }^{\circ} \mathrm{C}$. This is necessary to remove the water molecules physically bound to the soil (Fig. 1).

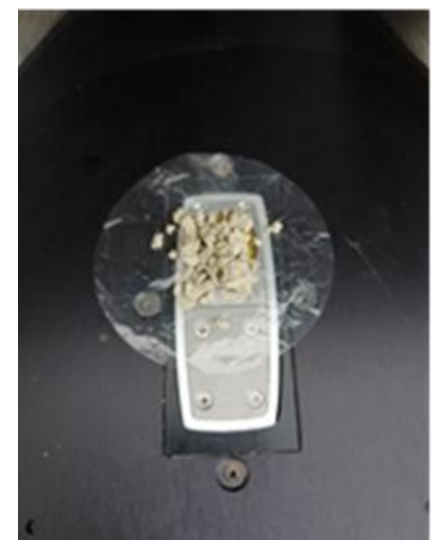

Fig. 1. Placement of the soil sample in the special place inside the analytical block of the X-ray fluorescence spectrometer

Table 1. Concentrations of metals corresponding to the 3 soil samples

\begin{tabular}{|c|c|c|c|c|c|}
\hline Sample & As [ppm] & Pb [ppm] & Rb [ppm] & Sr [ppm] & Zr [ppm] \\
\hline Sample 1 & 9 & 13 & 90 & 222 & 151 \\
\hline Sample 2 & 11 & 18 & 99 & 222 & 159 \\
\hline Sample 3 & 10 & 15 & 104 & 216 & 154 \\
\hline Limit values & $\mathbf{2 0}$ & $\mathbf{5 0 - 3 0 0}$ & $\mathbf{1 0 0 - 1 2 0}$ & $\mathbf{2 4 0}$ & $\mathbf{1 6 5}$ \\
\hline
\end{tabular}

The values of the determinations resulting from the analyses for the soil samples taken from the analysed perimeter were compared with the reference values according to the national norms in force, respectively MAPPM Order no. 756/1997 [6].

Table 1 comparatively presents the results of the analyses regarding the elemental concentrations corresponding to the 3 soil samples taken from different depths.

Figure 2 shows graphically and comparatively the results of the analyses regarding the elemental concentrations corresponding to the 3 soil samples taken from different depths.
It was observed that for the elements $\mathrm{As}, \mathrm{Pb}, \mathrm{Sr}$ and $\mathrm{Zr}$, the highest concentrations were revealed for sample 2, with the exception of Rb element. This can be explained by the fact that for soil sample 1 which was taken from the smallest depth $(10 \mathrm{~cm})$, the perimeter from which it was taken was subjected to rainfall and specific agricultural work, as it is known that the concentrations of pollutants are usually lower during precipitation.

Thus, the heavy metals analysed were "washed" and transported deeper into the soil, at a depth of 20 $\mathrm{cm}$, corresponding to soil sample 2. The lower concentrations of heavy metals in the case of soil 
sample 3, taken from a depth of $30 \mathrm{~cm}$ can be explained by the fact that the mechanism of transport of pollutants in the soil was through the liquid phase, because most metals enter the soil in forms dissolved or suspended in water and, in fact, all interactions that take place between heavy metals and solid soil constituents take place at the solid-liquid interface. In this case, the pollutants did not penetrate too deep into the soil.

For no heavy metals analysed, the permissible limit values were not exceeded, so the soil samples taken do not indicate exceeding the level for heavy metal pollution.

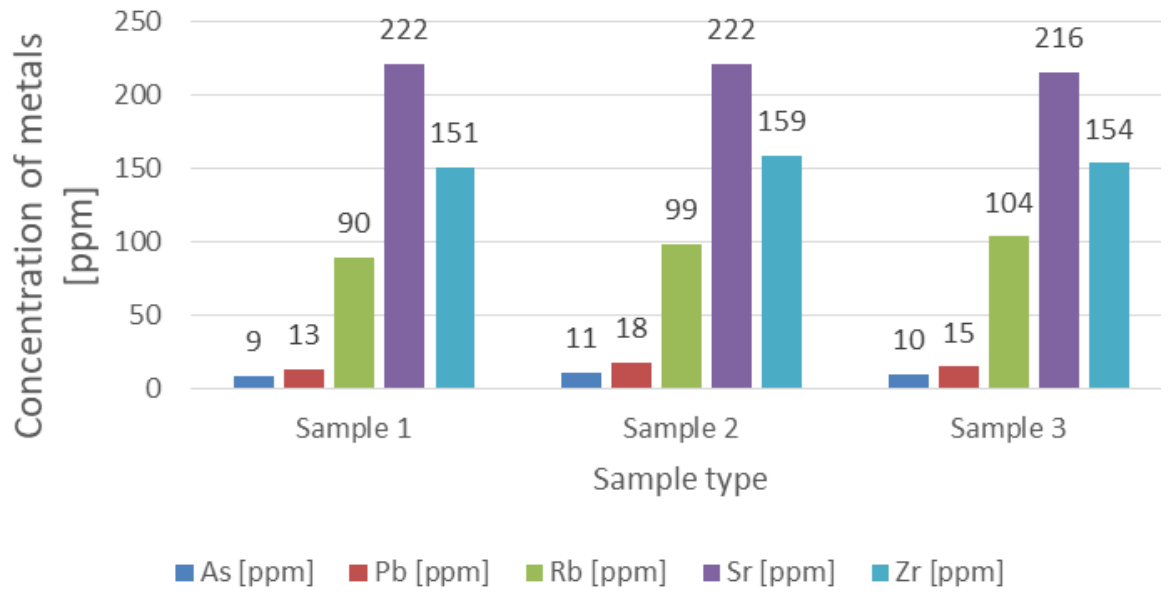

Fig. 2. Concentrations of heavy elements related to the 3 soil samples analysed

\subsection{Determination of the $\mathrm{pH}$ of soil samples}

Soil $\mathrm{pH}$ is one of the most common and indicative determinations of chemical properties, which specifies the acidic or basic character of the soil, indicating the type of crops suitable for each field, what type of fertilizer to apply or if necessary to correct the $\mathrm{pH}$ value of the soil. It also indicates the availability of essential nutrients, as well as the estimation of toxicity with certain elements $[9,10]$.

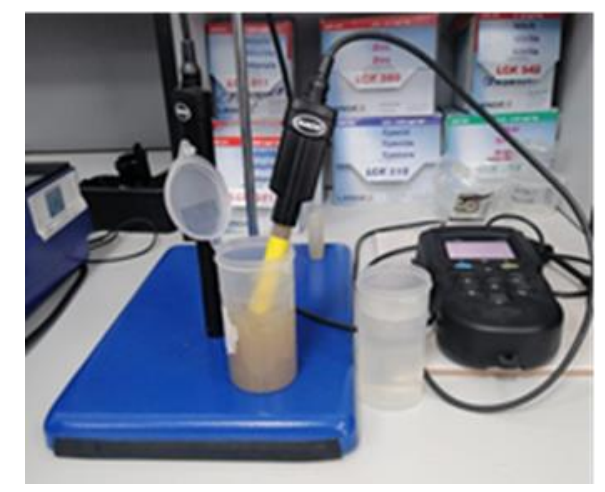

Fig. 3. PH measurement with soil-water suspension sample
Table 2 shows the $\mathrm{pH}$ values for the 3 types of samples studied and taken from different depths.

Table 2. PH values corresponding to the 3 soil samples

\begin{tabular}{|c|c|}
\hline Sample & pH \\
\hline Sample 1 & 7.60 \\
\hline Sample 2 & 7.99 \\
\hline Sample 3 & 7.97 \\
\hline Sample benchmark & 7.29 \\
\hline
\end{tabular}

Figure 4 shows graphically and comparatively the results of the analyses regarding the $\mathrm{pH}$ values corresponding to the 3 soil samples taken from different depths.

It was observed that, regardless of the depth from which the soil samples were taken, all measured $\mathrm{pH}$ values fell into the categories of "weakly alkaline" soils. As most plants support a $\mathrm{pH}$ in the low acid neutral - low alkaline range, these results confirm that the soil samples taken do not indicate exceeding the level for pesticide pollution and/or chemical fertilizers. 


\section{THE ANNALS OF "DUNAREA DE JOS” UNIVERSITY OF GALATI \\ FASCICLE IX. METALLURGY AND MATERIALS SCIENCE \\ No. 4 - 2021, ISSN 2668-4748; e-ISSN 2668-4756 \\ Article DOI: https://doi.org/10.35219/mms.2021.4.11}

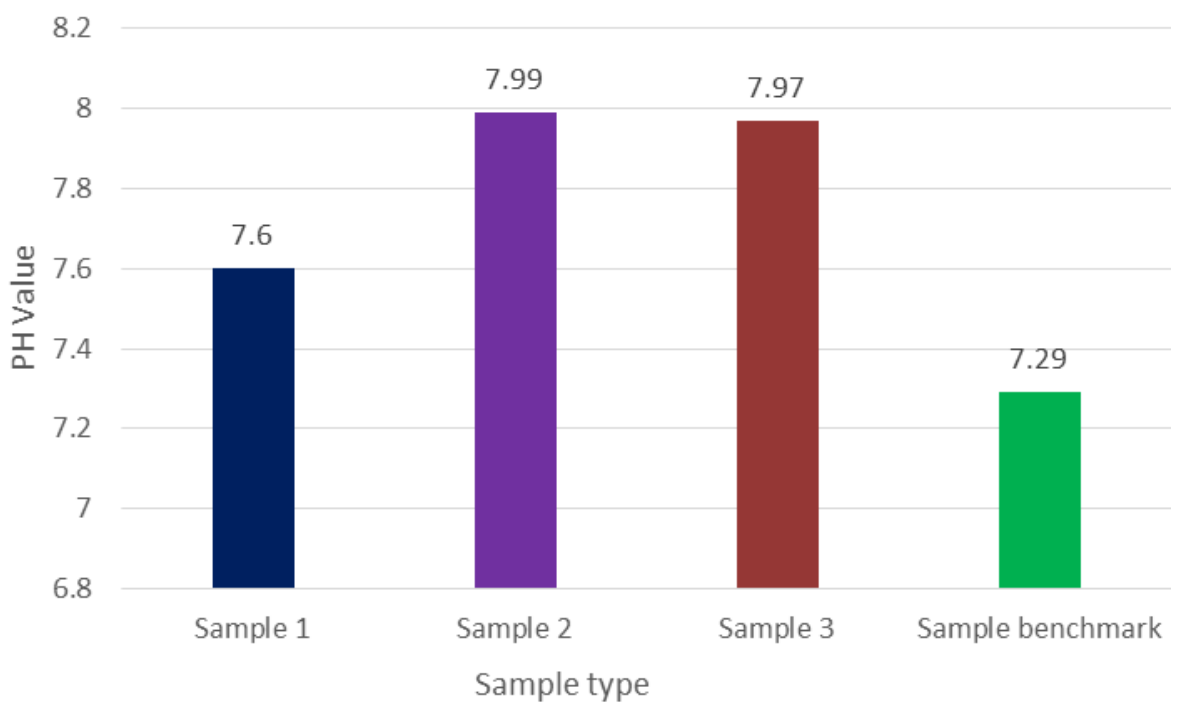

Fig. 4. The $p H$ values related to the 3 soil samples analysed

\subsection{Analysis of nitrate concentration in soil samples}

Nitrates are nitrogen compounds that occur naturally in the soil, but which can also be spread by fertilization. Plants use nitrate nitrogen for their own metabolism and to produce protein. Nitrate is extracted from the soil through the roots and is distributed throughout the plant to be converted into high-energy protein compounds through photosynthesis. The remaining surplus contaminates the groundwater, being found in rivers, lakes or groundwater and, ultimately, in drinking water. Nitrate levels in soil and drinking water can become considerable, depending on the predominant form of land use. Nitrates in the soil come from the fixation of atmospheric nitrogen by many plant species (legumes), being present even in the absence of nitrogen fertilization, but the latter being a major source of them [7].

For this type of assay, for maximum safety, were used predetermined LCK 340 reagents.
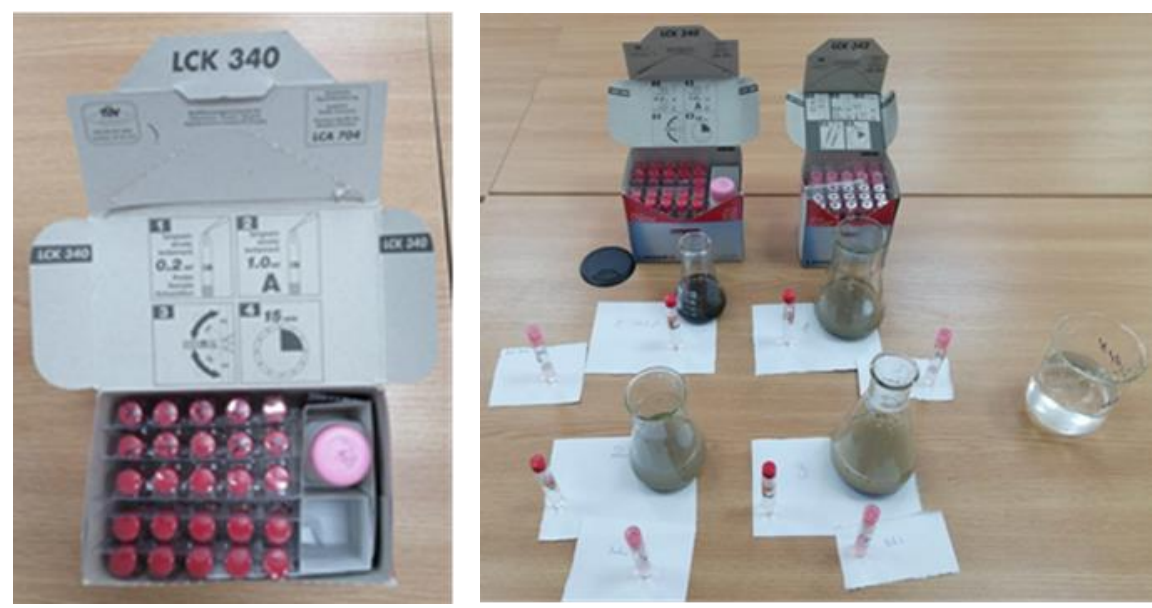

Fig. 5. Predetermined reagents LCK 340 for nitrate determinations

Table 3 shows the values of nitrate concentrations related to the 3 types of samples studied and taken from different depths.

From Table 3 and Figure 6 it can be seen that regardless of the depth of soil sampling, the values of nitrate concentrations did not exceed the maximum level of contamination. These results confirm that the soil samples taken do not indicate exceeding the level for pollution with pesticides and/or chemical fertilizers. It can also be seen that the nitrate concentration shows an increasing trend with depth. 


\section{THE ANNALS OF "DUNAREA DE JOS" UNIVERSITY OF GALATI \\ FASCICLE IX. METALLURGY AND MATERIALS SCIENCE \\ No. 4 - 2021, ISSN 2668-4748; e-ISSN 2668-4756 \\ Article DOI: $\underline{\text { https://doi.org/10.35219/mms.2021.4.11 }}$}

Table 3. Values of nitrate concentrations related to the 3 types of samples studied and taken from different depths

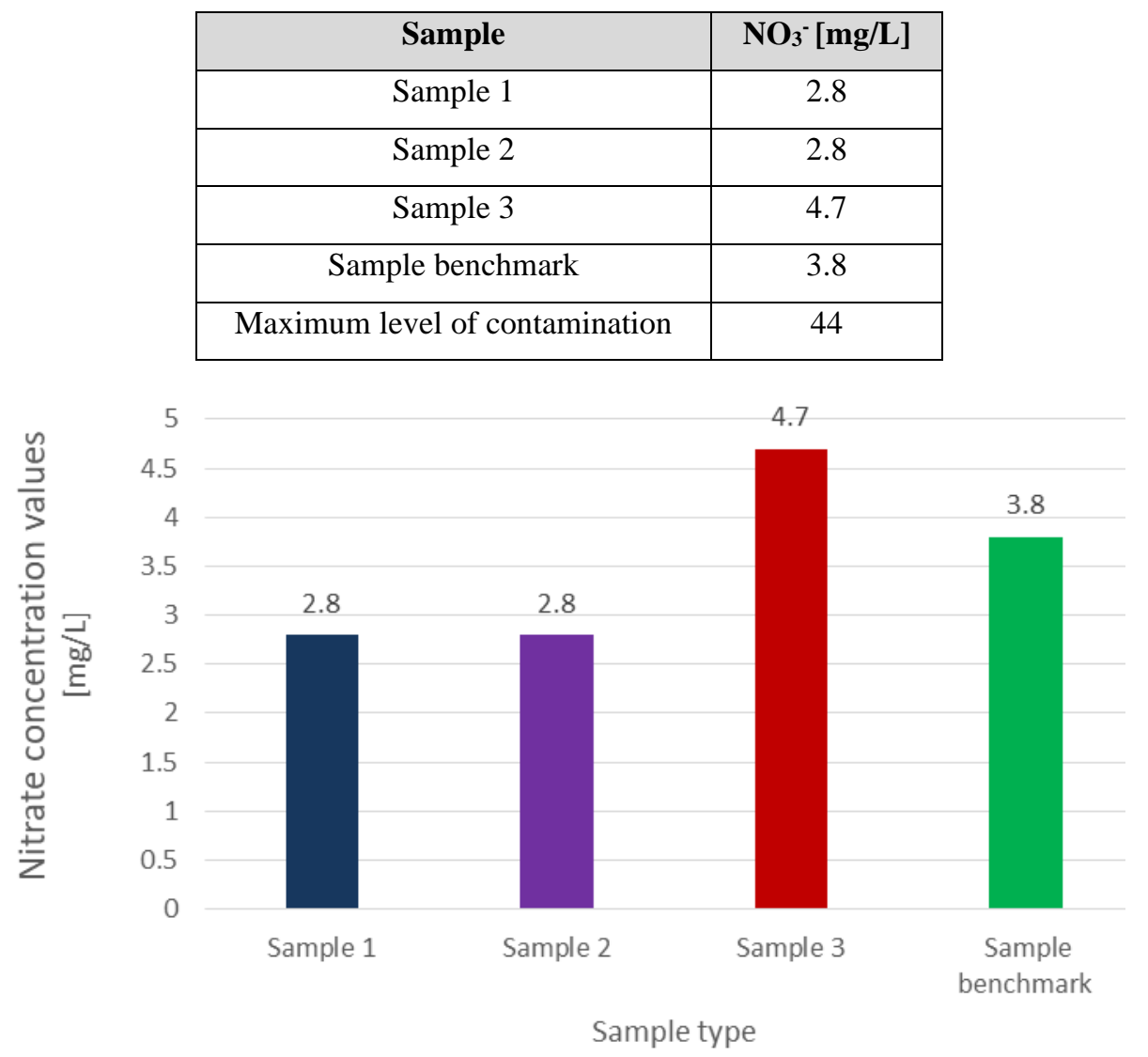

Fig. 6. The values of nitrate concentrations related to the 3 soil samples analysed

\subsection{Analysis of the nitrite concentration in the soil samples}

Nitrite is an intermediate product in the nitrogen supply process of the plant. Because plants cover their nitrogen requirements with nitrate, plant-based foods - especially various varieties of vegetables - can contain relatively large amounts of nitrogen. In vegetables that contain nitrates, microbiological or enzymatic processes can cause the conversion of nitrate to nitrite. This may be due to improper storage, improper transport or non-compliance with standard hygiene regulations.

For this type of assay, for maximum safety, were used predetermined LCK 342 reagents.

Table 4 indicates the values of nitrite concentrations related to the 3 types of samples studied and taken from different depths.

Figure 8 shows graphically and comparatively the results of the analyses regarding the values of nitrite concentrations corresponding to the 3 soil samples taken from different depths.

Table 4. Nitrite concentrations corresponding to the 3 soil samples

\begin{tabular}{|c|c|}
\hline Sample & $\mathbf{N O}_{2}{ }^{-}[\mathbf{m g} / \mathbf{L}]$ \\
\hline Sample 1 & 0.009 \\
\hline Sample 2 & 0.010 \\
\hline Sample 3 & 0.028 \\
\hline Sample benchmark & 0.009 \\
\hline $\begin{array}{c}\text { Maximum level of } \\
\text { contamination }\end{array}$ & 3.3 \\
\hline
\end{tabular}



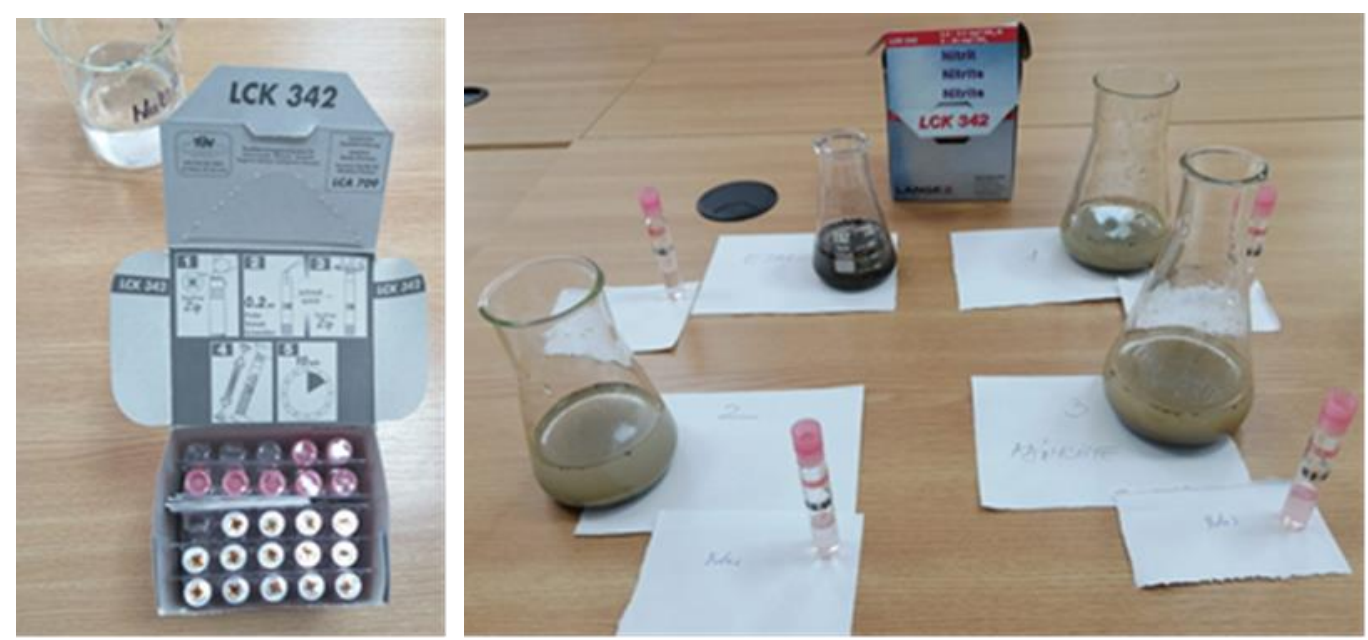

Fig. 7. Predetermined reagents LCK 342 for nitrite determinations

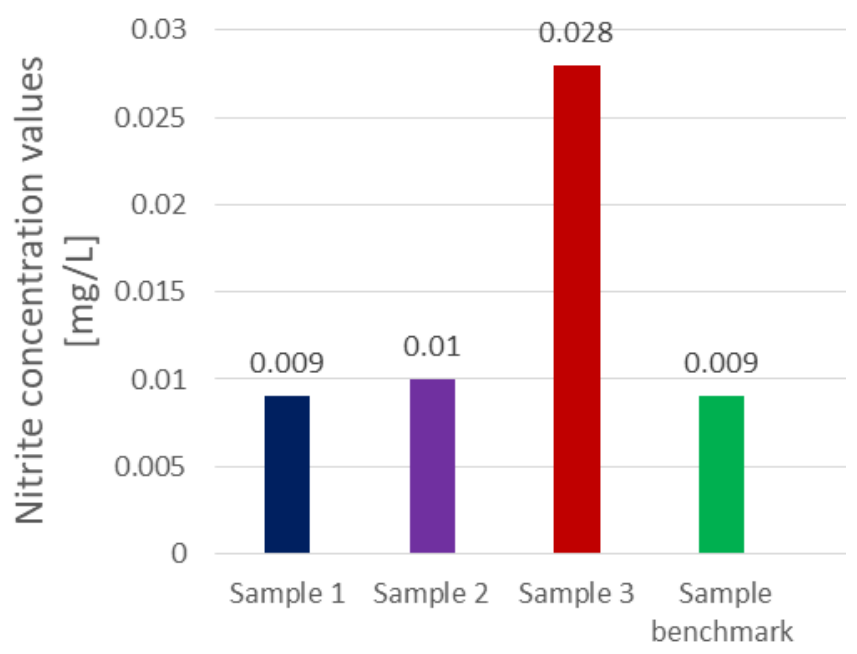

Fig. 8. The values of nitrite concentrations related to the 3 soil samples analysed

It was observed that regardless of the depth of soil sampling, the values of nitrite concentrations did not exceed the maximum level of contamination. These results confirm that the soil samples taken do not indicate exceeding the level for pollution with pesticides and/or chemical fertilizers.

It can also be seen that the nitrite concentration as in the case of nitrate concentrations shows an increasing trend with depth.

\section{Conclusions}

Following the analysis of the soil concentration, the determined elements fall within the limits imposed by the legislation in force on the limit values of heavy metals allowed in the soil, with the mention that in sample 2 (at a depth of $20 \mathrm{~cm}$ ), were recorded the highest values of the determined elements which shows us that these pollutants migrate into the depths of the soil by diffusion and dissolution having as solvent water. The soil samples taken do not indicate exceedances of the permitted limit values.

The measured $\mathrm{pH}$ values fall into the category of weakly alkaline soils being beneficial for agricultural crops.

Nitrate concentration shows an increasing trend with depth. The highest value of nitrates was obtained in sample 3. However, the nitrate concentrations from all the samples studied did not exceed the maximum level of contamination.

The nitrite concentration shows an increasing trend with the sampling depth, but the determined values do not exceed the maximum level of contamination allowed.

\section{References}

[1]. Lăcătuşu R., Agrochimie, Ed. Helicon, Timişoara, 2000. 


\section{THE ANNALS OF “DUNAREA DE JOS" UNIVERSITY OF GALATI \\ FASCICLE IX. METALLURGY AND MATERIALS SCIENCE \\ $\mathrm{N}^{\circ} .4$ - 2021, ISSN 2668-4748; e-ISSN 2668-4756 \\ Article DOI: https://doi.org/10.35219/mms.2021.4.11}

[2]. Lăcătușu R., Mineralogia şi chimia solului, Ed. Universităţi „Al. I. Cuza” Iaşi, 2000.

[3]. Lăcătuşu R., Kovacsovics Beatrice, Plaxienco Doina, Rîşnoveanu I., Lungu Mihaela, Mihalache Daniela, Încărcarea cu poluanţi proveniţi din îngrăşăminte şi pesticide a unor soluri, legume şi a apei freatice din partea sudică şi estică a municipiului Bucureşti; Lucr. Simpoz. „Protecţia Mediului în Agricultură”, vol. 1, p. 279-293, 2000.

[4]. Andreiaș S., Optimizarea regimurilor nutritive ale solurilor și productivitatea plantelor de cultură, Ed. Pontos, Chișinău, 2007.

[5]. Batjes N. H., Total carbon and nitrogen in the soils of the world, European J. Soil Sci., 47, p. 151-163, 1996.

[6]. Blair J., Fertilizer recommendations as determined by chemical and physical parameters of soil and $K$ requirement of crops, Potassium in Ecosystems, p. 79-90, 1992.
[7]. Borlan Z., Hera Cr., Aplicarea îngrăşămintelor pentru cultura intensivă a principalelor plante de câmp, Agrochimie, Ed. Lixandru şi colab., Ed. Didactică şi Pedagogică, p. 296-305, 1990.

[8]. Borlan Z., Gavriluță I., Stefănescu Daniela, Alexandrescu Ariadna, Nebunelea Dobriţa, Fertilizarea în cadrul unor sisteme de producţie vegetală durabilă. II. Potasiul, Şt. Solului XXXIII, 2, 1999.

[9]. Calancea L., Bazele agrochimice ale fertilizării în raport cu cerinţele plantelor, Agrochimie, Ed. Didactică şi Pedagogică, Bucureşti, p. 18-36, 1990.

[10]. Clapp C. E., Hayes M. H. B., Simpson A. J., Kingery W. L., Chemistry of soil organic matter in Chemical processes in soil, (Tabatabai A., Spark D., eds.) SSSA Book Series, no. 8, Madison, p. 1-150, 2005. 